\title{
PENGGUNAAN LONG-RANGE RFID READER UNTUK MEMPERMUDAH ASSET MANAGEMENT SYSTEM SEKOLAH
}

\author{
Maulana Ardhiansyah \\ Teknik Informatika, Fakultas Teknik, UniversitasPamulang \\ e-mail: maulana1402@gmail.com
}

\begin{abstract}
ABSTRAK
Banyak instansi khususnya sekolah masih menganggap manajemen aset secara fisik hanyalah sekedar instrumen pengelolaan daftar aset. Realita di lapangan menunjukan banyak kasus yang sebenarnya dimulai dari salah kelola dan salah urus masalah aset, sehingga berdampak kerugian yang tidak sedikit. Manajemen aset adalah serangkaian kegiatan yang terdiri dari indentifikasi aset apa yang dibutuhkan, memperoleh aset, menyediakan logistic dan sistem pendukung pemeliharaan dari asset dan penghapusan atau pembaharuan asset sehingga lebih efektif dan efisien. Untuk mempercepat dan memudahkan bagi pengguna di sekolah dalam memanajemen aset sekolah diperlukan fitur tambahan yaitu RFID (Radio-Frequency Identification) adalah sistem identifikasi tanpa kabel yang memungkinkan pengambilan data tanpa harus bersentuhan. Prototipe adalah pengembangan yang cepat dan pengujian terhadap model kerja prototipe dari aplikasi baru melalui proses interaksi dan berulang-ulang yang biasa digunakan ahli sistem informasi dan ahli bisnis. Prototipe disebut juga desain aplikasi cepat (rapid application design atau RAD) karena menyederhanakan dan mempercepat desain sistem. Dengan adanya sistem manajemen aset yang baru, modern, sistematis, valid dan real time dapat memudah pekerjaan mengelola aset sekolah dengan baik dan benar, dan dapat meminimalisir kerugian yang terjadi akibat kesalahan dalam pengelolaan Aset di sekolah.
\end{abstract}

Kata Kunci: Aset manajemen, RFID, prototype, Sekolah

\section{PENDAHULUAN}

Aset merupakan hal yang sangat penting bagi suatu instansi. Menurut Hwa (2003) dalam Sri Lankan Journal of Estate, sejalan dengan kebutuhan akan tempat usaha, properti digambarkan sebagai faktor penting dari produksi. Hal ini menjelaskan mengapa banyak instansi mempunyai aset properti dalam jumlah besar (Seiler et al, 2001 dalam Sri Lankan Journal of Estate). Berkaitan dengan hal tersebut, maka aset properti dalam jumlah yang besar harus dapat dikelola dengan baik.

Banyak instansi masih menganggap manajemen aset secara fisik hanyalah sekedar instrumen pengelolaan daftar aset. Realita di lapangan menunjukan banyak kasus yang sebenarnya dimulai dari salah kelola dan salah urus masalah aset, sehingga berdampak kerugian yang tidak sedikit. Sebagai contoh optimalisasi sumber daya tidak bisa dilakukan secara maksimal karena tidak teridentifikasi dengan jelas, sehingga sulit untuk memenejemen alat-alat tersebut apakah suatu alat produksi sudah saatnya untuk diganti atau masih layak untuk di maintenance. Pertanyaan berikutnya bagaimana mengetahui pergerakan setiap aset yang masuk dan keluar setiap harinya, baik untuk keperluan peminjaman aset atau maintenance. Dan apakah semua barang yang selesai dipinjam telah kembali kedalam ruangannya kembali. Semua hal itu akan menjadi masalah jika masih dilakukan secara manual tanpa bantuan suatu alat atau sistem yang memenejemennya.

\section{LANDASAN TEORI}

Pengertian sistem mengandung arti kumpulan-kumpulan dari komponenkomponen yang dimiliki unsur keterkaitan antara satu dengan lainnya (Indrajit, 2001).

Manajemen aset adalah serangkaian kegiatan yang terdiri dari indentifikasi aset apa yang dibutuhkan, memperoleh aset, menyediakan logistic dan sistem pendukung pemeliharaan dari aset dan penghapusan atau pembaharuan aset sehingga lebih efektif danefisien (Nicholas Hastings A. J, 2010).

Prototipe desain antarmuka merupakan contoh atau simulasi dari layar komputer, formulir, atau laporan. Prototipe merupakan 
persiapan dari masing-masing antarmuka untuk ditunjukkan kepada pengguna dan programer bagaimana suatu sistem ditampilkan (Alan Dennis dkk, 2005).

Arduino adalah pengendali mikrosingleboard yang bersifat open-source, diturunkan dari Wiringplatform, dirancang untuk memudahkan penggunaan elektronik dalam berbagai bidang. Hardwarenya memiliki prosesorAtmel AVR dan softwarenya memiliki bahasa pemrograman sendiri. Saat ini Arduino sangat populer di seluruh dunia. Banyak pemula yang belajar mengenal robotika dan elektronika lewat Arduino karena mudah dipelajari. Tapi tidak hanya pemula, para hobbyist atau profesional pun ikut senang mengembangkan aplikasi elektronik menggunakan Arduino. Bahasa yang dipakai dalam Arduino bukan assembler yang relatif sulit, tetapi bahasa $\mathrm{C}$ yang disederhanakan dengan bantuan pustakapustaka (libraries) Arduino.

Raspberry Pi atau Raspi adalah komputer kecil seukuran sebuah kartu kredit, Raspberry Pi memiliki prosesor, RAM dan port hardware yang khas yang bisa anda temukan pada banyak komputer. Ini berarti, Anda dapat melakukan banyak hal seperti pada sebuah komputer desktop. anda dapat melakukan seperti mengedit dokumen, memutar video HD, bermain game, coding dan banyak lagi. Sangat jelas sekali, Raspi tidak akan memiliki kekuatan atau tidak se-powerfull seperti desktop PC. tapi karena harganya yang jauh lebih murah maka kita bisa mengoprek dan memodifikasi tanpa memikirkan harganya. Raspberry Pi juga bagus dalam melakukan banyak hal yang tidak membutuhkan komputer mahal untuk membuatnya. seperti berjalan sebagai NAS (NetworkAttachedStorage), webserver, router, media center, TorrentBox dan masih banyak lagi. Sistem operasi utama untuk Pi adalah RaspbianOSdan didasarkan dari Debian (basedondebian). Ini adalah distribusi linux sehingga anda mungkin akan merasa sedikit berbeda jika anda sering menggunakan komputer windows. Meskipun sistem operasi yang didukung utama adalah raspbian anda juga dapat menginstal sistem operasi lain seperti Ubuntu core dan Ubuntu mare, Pirate OS, OSMC, RIS OS, Windows 10 IOT dan banyak lagi.

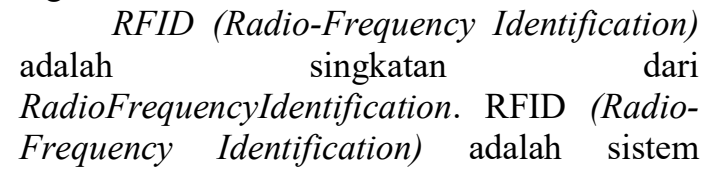

identifikasi tanpa kabel yang memungkinkan pengambilan data tanpa harus bersentuhan seperti barcode dan magneticcard seperti ATM. Rintisan tegnologi RFID (RadioFrequency Identification) dimulai saat seorang mata-mata Uni soviet (Rusia) menemukan sistem pengiriman gelombang radio melalui informasi audio. Gelombang suara yang menggetarkan diagfragma yang telah dibentuk menjadi sebuah resonator yang memodulasi gelombang radio yang terpantul. Meskipun alat ini bukan sebuah identifikasi namun dianggap sebagai pendahulu teknologi RFID (RadioFrequency Identification). Selain itu ada juga teknologi transponder IFF yang digunakan oleh tentara inggris pada perang dunia ke-2 untuk mengidentifikasi pesawat sebagai teman atau musuh. Perangkat RFID (Radio-Frequency Identification) yang menjadi cikal bakal sistem RFID (Radio-Frequency Identification) modern adalah Perangkat Mario Cardullo, karena menggunakan transponderradiopasif dengan memori. Paten dasar Cardullo meliputi penggunaan RF, suara dan cahaya sebagai media transmisi. RFID (Radio-Frequency Identification) ditawarkan kepada investor pada tahun 1969 meliputi penggunaan dalam bidang transportasi, perbankan, keamanan dan medis.

\section{METODE PENELITIAN}

Di dalam analisis ini akan menjelaskan apa saja proses sistem informasi yang diusulkan. Karena data yang digunakan selama sebelumadasistem yang akan dibuat, admin sekolah yang mengurusi bagian peminjaman asset sekolah ini memproses dengan aplikasi yang familiar dipakai yaitu microsoft excel. Untuk itu data dalam excel harus di migrasikan kedalam sistem yang terbagi dalam 2 tahap yaitu proses upload jenis kelas dan kode kelasnya. Setelah itu proses upload data asset sekolah yang akan di migrasikan kedalam database. 


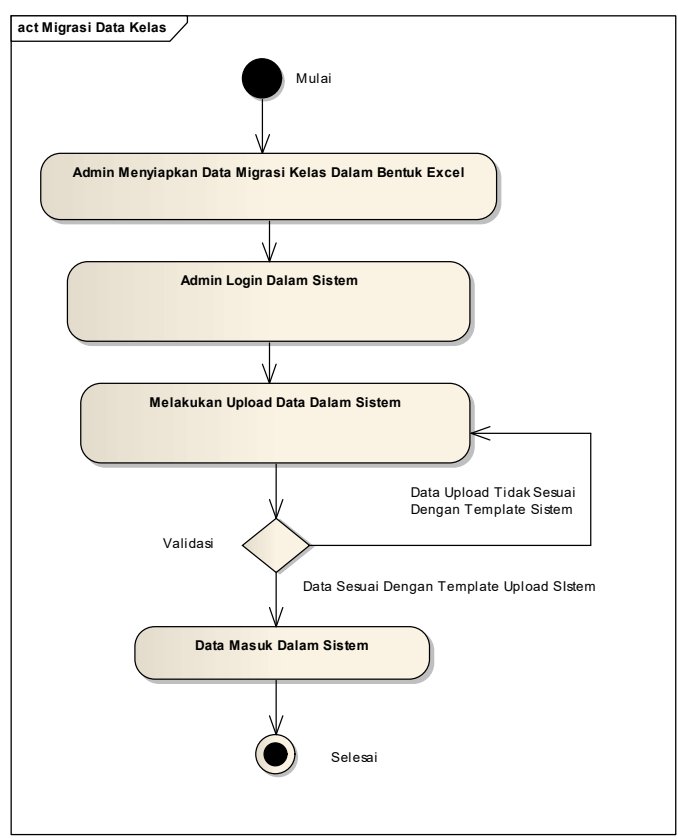

Gambar 1.Activity Proses Upload Data Kelas

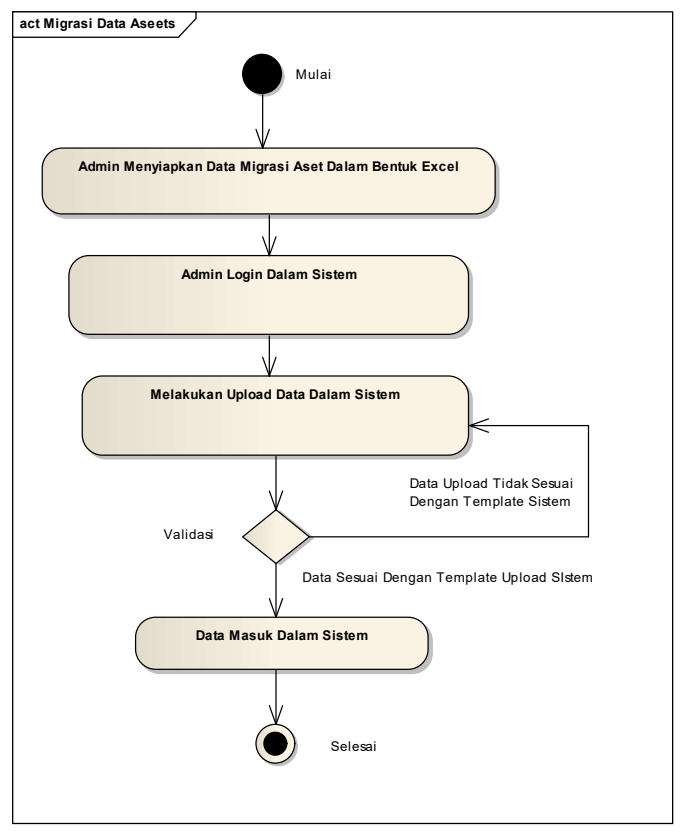

Gambar 2.Activity Proses Upload Data Aset Sekolah

\section{a. Proses Editing Data Aset}

Pada tahap ini admin diberi kewenangan untuk mengedit data asset sekolah. Baik dari nama aset yang dapat diganti, status aset, fotoaset, dan keterangan lain-lain yang menjelaskan criteria asset tersebut. Setelah tahap ini asset sudah siap untuk dipinjam.

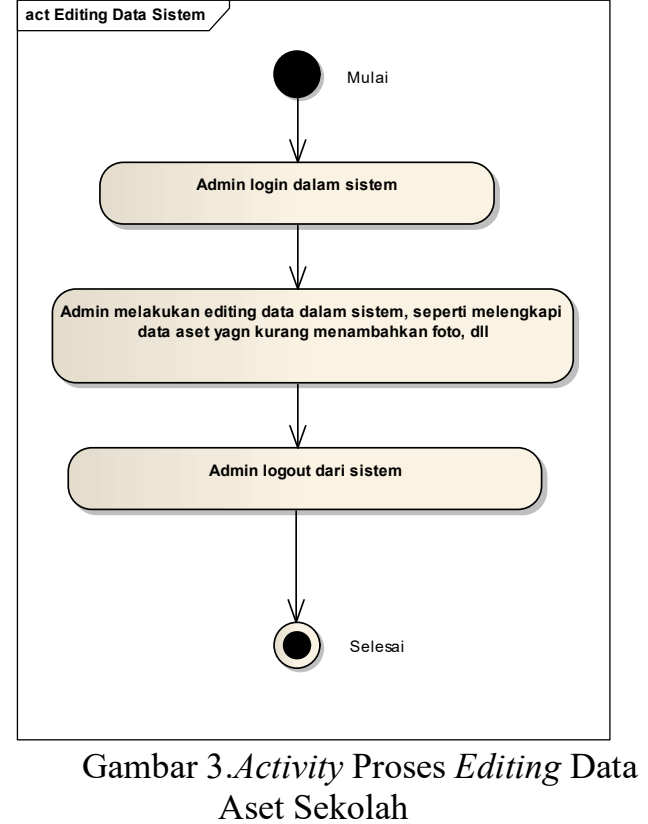

\section{b. Proses Peminjaman Aset}

Pada tahap ini user dapat melihat daftar asset sekolah yang tersedia untuk dipinjam, user hanya perlu memasukan tanggal peminjaman dan tanggal pengembalian aset tersebut. Setelah itu tinggal menunggu status penyetujuan peminjaman dari admin.

\section{c. Proses Penyetujuan Peminjaman Aset}

Pada tahap ini admin dapat melakukan penyetujuan atau penolakan terhadap pengajuan peminjaman user. Apabila peminjaman disetujui user dapat langsung mengkonfirmasi admin untukmelakukan pengambilan aset yang dipinjam. Dan bila pengajuan ditolak maka daftar pengajuan akan terhapus dalam daftar user 


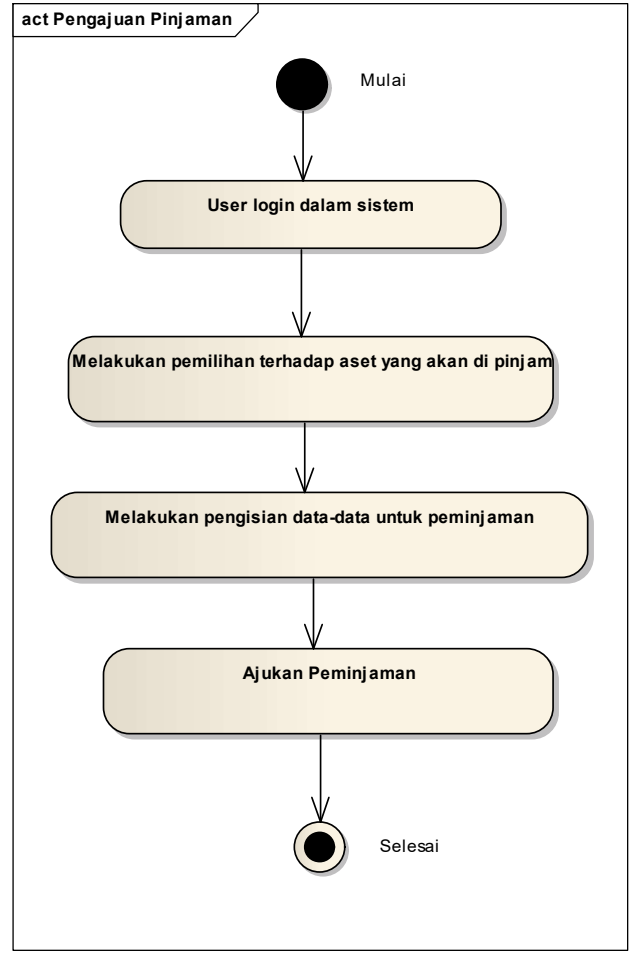

Gambar 4. Activity Proses Peminjaman

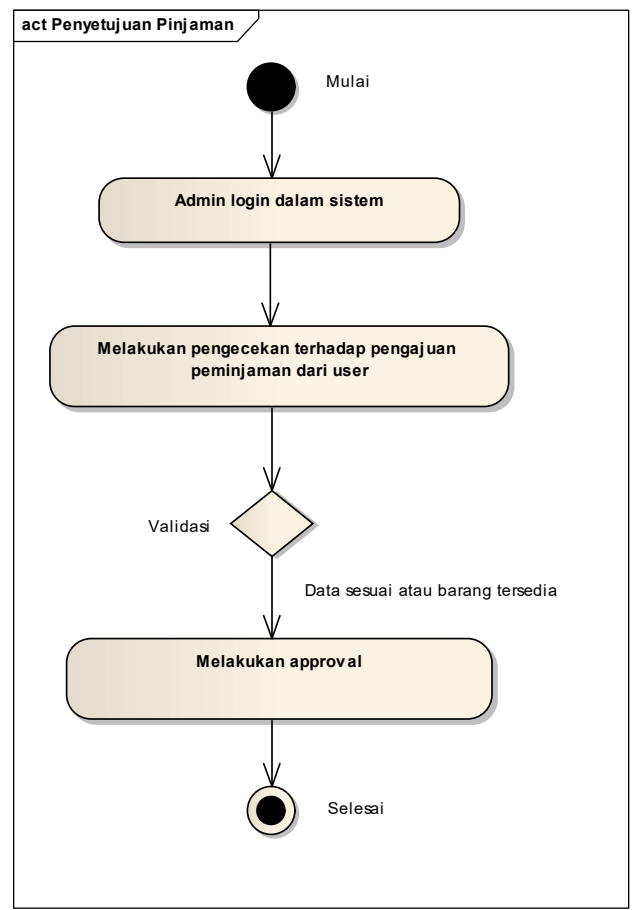

Gambar 5.Activity Proses Penyetujuan Peminjaman

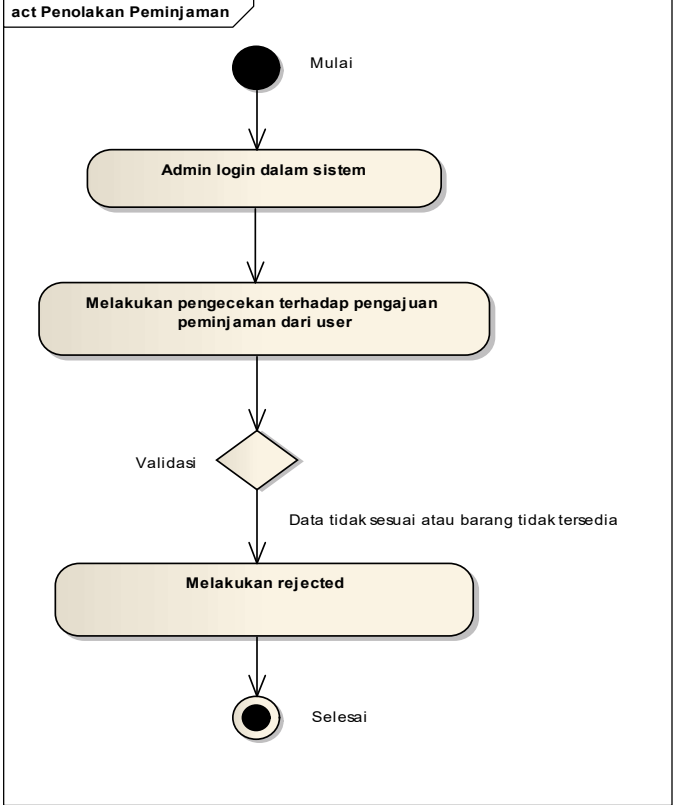

Gambar 6. Activity Proses Penolakan Peminjaman

\section{d. Proses Pelacakan Aset}

Pada tahap ini aset yang telah diajukan untuk dipinjam sudah memiliki tanggal kapan harusnya barang keluar, dan oleh siapa barang itu di pinjam. Jika asset tersebut keluar bukan dari jadwal yang sudah disetujui RFID akan membunyikan alarm, pertanda bahwa ada masalah terhadap barang tersebut.

Jika aset di bawa pada tanggal yang benar maka RFID akan mencatat keberadaannya, dan mengupdate status terakhir barang tersebut dari beberapa tempat, yaitu area kelas, area gedung sekolah dan area pos satpam. RFID akan memberikan status terakhir sampai barang tersebut keluar dari area sekolah. 


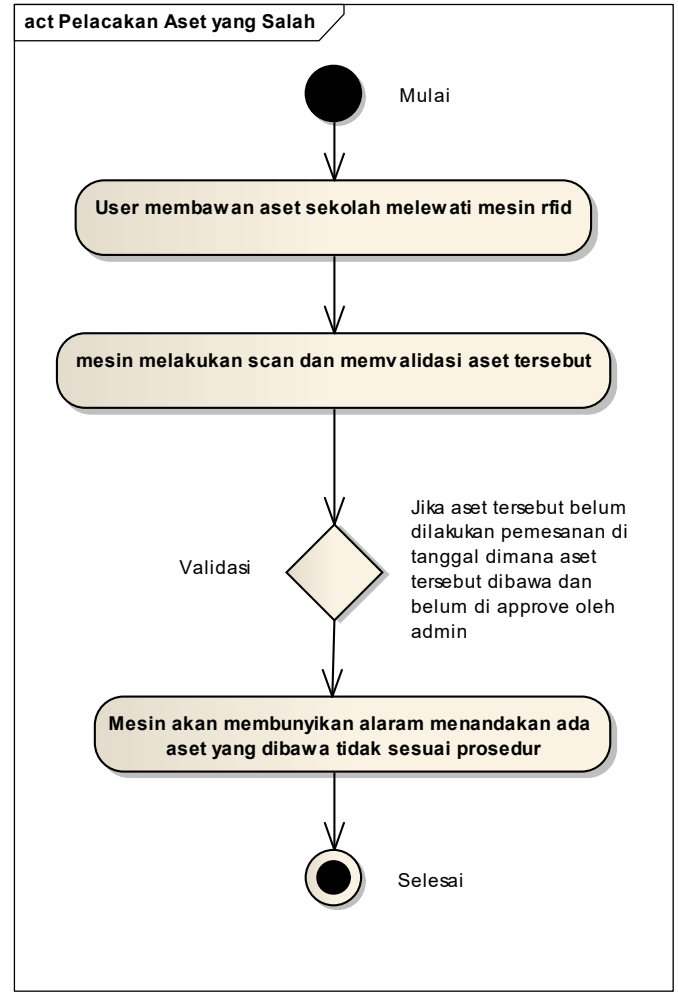

Gambar 7. Activity Proses Peminjaman yang Salah

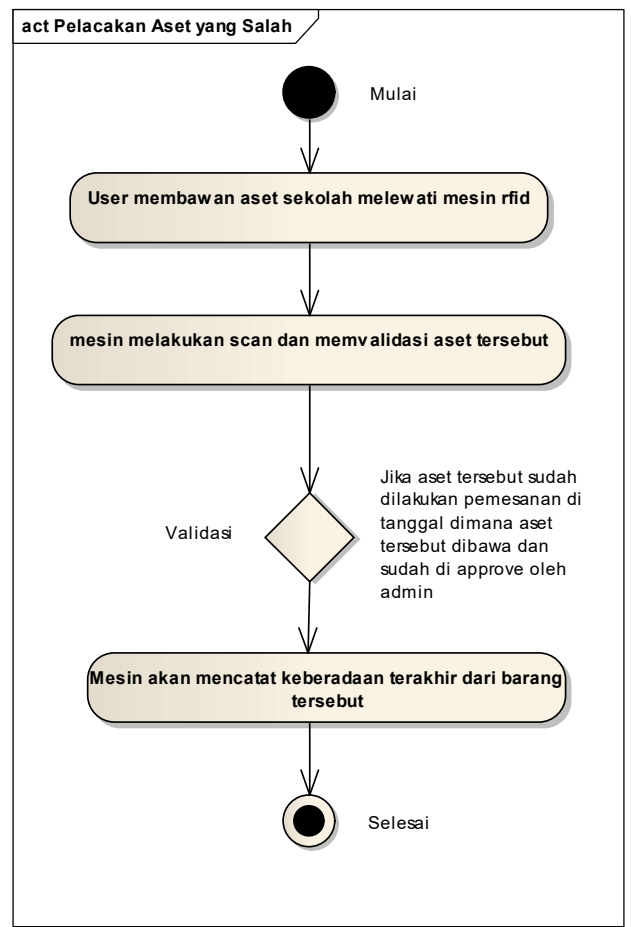

Gambar 8. Activity Proses Peminjaman yang Benar

\section{PEMBAHASAN}

Terdapat 2(dua) jenis implementasi, yaitu implementasi perangkat keras untuk alat scanner dan perangkat lunaknya.

Implementasi perangkat keras untuk scanner.

a. Mesin scanner RFID dengan tipe range long distance, yang memungkinkan scanning barang dari jarak jauh.

b. Arduino nano yang sudah di modifikasi dan hanya diambil beberapa port yang dibutuhkan saja.

c. ESP 8266 sebagai penangkap wireless juga sebagai sarana transaportasi data dari arduino ke raspberry pi.

d. Box panel ukuran $0.5 \times 0.5 \mathrm{~m}$ untuk case atau pelindung raspberry pinya.

e. Layar LCD ukuran 1/4 m yang ditempel didepan box panel untuk menampilkan data yang didapat.

f. PCB ukuran 5-10 cm untuk tempat komunikasi arduino dan esp 8266.

g. Kabel jumper yang digunakan arduino untuk berkomunikasi dengan arduino lain atau esp 8266.

Implementasi perangkat keras untuk web aplikasi: Raspberry pi 3, ini adalah jenis personalcomputer mini yan gunakan sebagai server dari web aplikasi.

Perangkat lunak yang digunakan untuk mengimplemetasikan sistem adalah sebagai berikut:

a. Web browser (Google chroome atau Chromium).

b. LAMPP (Linux, Apache, Mysql, PHP, Pearl).

c. PHP Laravel 5.2 ini adalah framework dari PHP.

d. PHP artisan untuk command line di linux dan juga untuk laravel.

Berdasarkan Implementasi maka bentuk antarmuka yang akan ditampilkan menjadi 3 (tiga) bagian yaitu antarmuka untuk public, pengguna dan administrator (admin).

a. Halaman untuk public.

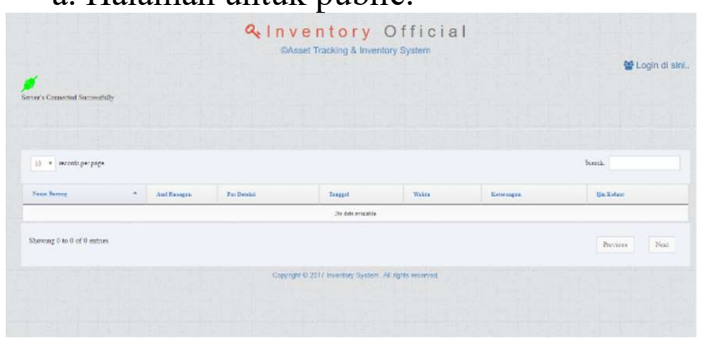


Gambar 9. Tampilan Dashboard.

c. Halaman untuk pengguna atau user.

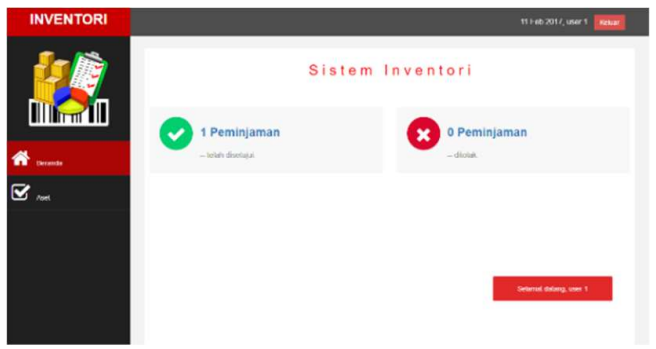

Gambar 10. Tampilan Beranda User

c. Halaman untuk administrator (admin).

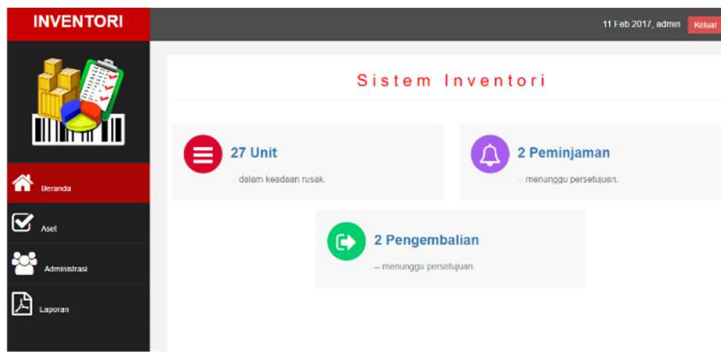

Gambar 11. Tampilan Beranda Admin

\section{KESIMPULAN}

Penggunaan RFID pada sistem manajemen aset yang baru, modern, sistematis, valid dan real timedapat memudah pekerjaan mengelola aset sekolah mulai barang masuk samapai barang tersebut kembali ke tempat semula semua dapat dipantau langsung keberadaanya. Serta semua laporan aset tersebut disajikan lengkap dan real time dengan kondisi sebenarnya serta laporan bersifat historicle.

\section{SARAN}

Saran untuk penelitian selanjutnya dapat dibuat dengan menggunakan API pada setiap route yang dipakai sehingga dapat digunakan untuk pengembangan versi mobilenya.

\section{DAFTAR PUSTAKA}

Hastings, Nicholas A. J.2010. Physical Asset Management. Edisi pertama. London: Springer.

O'Brien, James A. (2005). Pengantar Sistem Informasi: Persefektif Bisnis dan Manajerial. (12th edition). Salemba edition. Salemba Empat, Jakarta.

Al Fatta, Hanif. 2007, "Analisis dan perancangan sistem informasi. Yogyakarta: Andi".

Agus Mulyanto. 2009. Sistem Informasi Konsep dan Aplikasi. Pustaka Pelajar.Yogyakarta

Dennis, Alan; Wixom, Haley Barbara: \& Tegarden, David. 2005. Systems Analysis and Design with UML Version 2.0 : An Object-Oriented Approach. Second Edition. United States of America : John Wiley \& Sons, Inc.

Indrajit, 2001, Analisis dan Perancangan Sistem Berorientasi Object. Bandung, Informatika.

Ikatan Akutansi Indonesia. 2007. Standar Akuntansi Keuangan Per 1 September 2007. Jakarta : Penerbit Salemba Empat

Jogiyanto, Hartono. 2005. Analisis dan Desain Sistem Informasi, Edisi III. Yogyakarta: ANDI.

Kusrini. 2007:279. Konsep dan aplikasi sistem pendukung keputusan. penerbit Andi, Yogyakarta.

Robert G Murdick, dkk, Sistem Informasi Untuk Manajemen Modern, Jakarta: Erlangga, 1991.

Rosa A.S dan Salahuddin. M, "Rekayasa perangkat lunak", 2end ed, Bandung: Informatika, 2015.

The American Association of State Highway and Transportation Official. 2007. 21st Century Asset Management. http://www.ttap.mtu.edu/publications/ $2007 / 2$

1st_Century_Asset_Management.pdf. Diakses pada tanggal 21 Oktober 2016 